\title{
Sulfo- and Oxy-analogues of Arginine: Synthesis, Analysis and Preliminary Biological Screening ${ }^{\dagger}$
}

\author{
Tatyana Dzimbova, ${ }^{\text {a }}$ Elisaveta Miladinova, ${ }^{\mathrm{a}}$ Stefan Mohr, ${ }^{\mathrm{b}}$ Roumyana Decheva ${ }^{\mathrm{a}}$ \\ Aneliya Balacheva, ${ }^{a}$ Martin G. Schmid, ${ }^{b}$ and Tamara Pajpanova, ${ }^{a}, *$ \\ ${ }^{a}$ Institute of Molecular Biology, Bulgarian Academy of Sciences, BG-1113 Sofia, Bulgaria \\ ${ }^{\mathrm{b}}$ Institute of Pharmaceutical Sciences, Department of Pharmaceutical Chemistry, \\ Karl-Franzens-University, A-8010 Graz, Austria
}

RECEIVED OCTOBER 15, 2010; REVISED SEPTEMBER 26, 2011; ACCEPTED OCTOBER 10, 2011

\begin{abstract}
A novel methodology for the synthesis of sulfo- and oxy-modified amino acid analogues of arginine (Arg) has been developed using both conventional and polymer assisted synthesis from ready available amino acid precursor. Introduction of guanidine group was made also by the MWA synthesis. The in vitro inhibitory effect of the amino acid analogues on the growth of murine erythroleukemia cells, clone F4N in culture was also studied. (doi: 10.5562/cca1780)
\end{abstract}

Keywords: canavanine, mimetics, polymer assisted synthesis, micro wave assisted synthesis, erythroleukemia cells

\section{INTRODUCTION}

As the building blocks of peptides and proteins, amino acids are vitally important biochemical species. A detailed knowledge of their chemical properties is essential to understanding the complex interplay between amino acid structure and biological function.

One of the most prominent members of coded amino acids is arginine (Arg), which has been intensively studied with the respect to biological properties and as a building block in peptide chemistry. ${ }^{1}$ Arginine, guanidine-containing amino acid, plays an important role in biologically active proteins and peptides and is involved in many important physiological and pathophysiological processes. ${ }^{2-4}$ The guanidino group of Arg is the important detail of its biological specificity, a group with a high $\mathrm{p} K$ that is positively charged at all biologically relevant $\mathrm{pH}$ values. A highly basic guanidino moiety incorporated in enzyme inhibitors or receptor antagonists is however, often associated with low selectively, excreted rapidly, or do not pass biological membranes resulting in a poor bioavailability.

A significant effort has therefore been focused on the design and preparation of arginine analogues which possess reduced basicity, resulting in increased stability towards enzymatic degradation. ${ }^{5}$
In this context, we have focused on the design and synthesis of unnatural amino acids and their derivatives, containing a basic functionality (oxy- and sulfoguanidino), as structural analogues of arginine (Arg) and canavanine (Cav). ${ }^{6-9}$ Their effects on the growth of microorganisms, model plant systems, cultured tumor cells and their antitumor activity in vivo have been evaluated. ${ }^{10,11}$ In addition to their interesting biological properties, these unnatural amino acids were incorporated into biologically active peptidomimetics. ${ }^{12-15}$

Consequently, these studies emphasize the need of milder and more practical conditions for preparation of these arginine analogues.

In this article we report optimization of the synthesis of previously described oxy- and sulfo-analogues of arginine. $^{8,9,16}$ The optimization strategy included a polymer assisted synthesis (PAS) methodology, which combines advantages of traditional solution phase chemistry with application of polymeric agents. Moreover, the introduction of guanidine group was made also by the micro wave assisted (MWA) synthesis. This approach led to the desired compounds in a high throughput manner, in sufficient purity, without additional purification steps.

The in vitro inhibitory effect of the amino acid analogues on the growth of murine erythroleukemia cells, clone F4N in culture was also studied.

\footnotetext{
$\uparrow$ Presented at the $10^{\text {th }}$ International Symposium and Summer School on Bioanalysis within the CEEPUS Network CII-HU-001004-0910, Zagreb, Croatia, July 2010.

* Author to whom correspondence should be addressed. (E-mail: tamara@bio21.bas.bg)
} 


\section{EXPERIMENTAL}

\section{Materials and Methods}

All chemicals were of analytical grade. All anhydrous solvents were obtained commercially (Fluka) and used directly. HPLC-grade acetonitrile and $\mathrm{MeOH}$ were purchased from Merck. The Wang resin (100-200 mesh, $0.5-1.3 \mathrm{mmol} \mathrm{g}^{-1}$ ) was obtained from Navabiochem $^{\circledR}$ (Switzerland). MWA synthesis was performed on Microwave oven, Model MARS-X, CEM Corporation. Analytical TLC was performed on Merck silica gel $\left(60 \mathrm{~F}_{254}\right)$ plates $(0.25 \mathrm{~mm})$ using of the following solvent systems: A: $V$ (chloroform) $: V$ (methanol $): V($ water $)=80: 30: 5 ; \quad \mathrm{B}: V($ benzene $): V($ acetone $):$ $V($ acetic acid $)=100: 50: 2$; C: $V($ chloroform $): V($ methanol) $:($ acetic acid $)=95: 5: 5$. Visualization was done with either UV, ninhydrin or a chlorine tolidine reagent. Melting points were determined on a Büchi melting point apparatus and are uncorrected. Optical rotation was measured with a Perkin-Elmer Model 141 polarimeter. IR spectra were recorded on Specord-71-IR (Zeiss) or Bruker $113 \mathrm{~V}$ spectrophotometers. ${ }^{1} \mathrm{H}$ NMR spectra were recorded on Bruker WM-250 and Avance DRX-250 (250 MHz) spectrometers. Mass spectra were recorded on an Fissons-Triple Quadrupol-ES mass spectrometer. HPLC analyses were performed on Agilent Technologies HP 1100 and Dionex, Ultimate ${ }^{\circledR} 3000$ LC instruments, using a Beckman Ultrasphere ${ }^{\mathrm{TM}} \mathrm{RPC}_{18}$ $(250 \times 4.6 \mathrm{~mm}, 5 \mu \mathrm{m})$ and $\mathrm{ZIC}^{\circledR}$-HILIC $(100 \times 4.6 \mathrm{~mm}$, $5 \mu \mathrm{m})$ columns. Chiral analyses were performed on micro-HPLC using microbore column packed with the macrocyclic antibiotic Ristocetin A immobilized on 3.5 $\mu \mathrm{m}$ silica gel $(100 \times 1 \mathrm{~mm})$ from ASTEC (Whippany, NJ, USA). Dulbecco's modified Eagle medium was purchased from Gibco (Grand Island, NY).

\section{Synthesis}

\section{Z-Ser(OMes)-OBzl (2)}

To the solution of Z-Ser-OBzl (1.2 g, $4 \mathrm{mmol})$ in DCM $(10 \mathrm{ml})$ at $-10{ }^{\circ} \mathrm{C}$ DIPEA $(13.79 \mathrm{ml}, 80 \mathrm{mmol})$ was added, and after that Mes-Cl $(0.62 \mathrm{ml}, 8 \mathrm{mmol})$ dropwise. The reaction mixture was stirred for 2 hours at room temperature. Product (2) was obtained without further purification after evaporation of the solution in vacuo $(1.6 \mathrm{~g}, 70 \%)$ and it was used for the next step.

\section{$\mathrm{Z}-\mathrm{CH}\left(\mathrm{CH}_{2} \mathrm{SO}_{3} \mathrm{H}\right)-\mathrm{OBzl}(3)$}

Method I: 2 (0.4 g, $1 \mathrm{mmol})$ was suspended in water (2 $\mathrm{ml})$ and a solution of $\mathrm{Na}_{2} \mathrm{SO}_{3}(0.6 \mathrm{~g}, 5 \mathrm{mmol})$ in water $(5 \mathrm{ml})$ was added. The reaction mixture was stirred at room temperature for 24 hours. After acidification a new product (3) was obtained as white crystals from the reaction mixture. It was filtered out, washed with water and dried in vacuo $(0.3 \mathrm{~g}, 75 \%$ yield $)$.
Method II. The same as in method I, but with the following conditions at microwave irradiation (300 W), $1 \mathrm{~min}$ to $40^{\circ} \mathrm{C}$, hold $5 \mathrm{~min}(0.35 \mathrm{~g}, 87 \%$ yield $)$.

\section{$\mathrm{Z}-\mathrm{Cys}\left(\mathrm{SO}_{2} \mathrm{Cl}\right)-\mathrm{OBzl}(4)$}

To the solution of $3(0.2 \mathrm{~g}, 0.5 \mathrm{mmol})$ in DCM $(5 \mathrm{ml})$ at $-5{ }^{\circ} \mathrm{C}, \mathrm{SOCl}_{2}(0.18 \mathrm{ml}, 2.5 \mathrm{mmol})$ was added dropwise. Reaction mixture was stirred at $0{ }^{\circ} \mathrm{C}$ for 2 hours. DCM was evaporated in vacuo and $\mathbf{3}$ was obtained as a white solid (0.11 g, $57 \%$ yield).

\section{$\mathrm{Z}-\mathrm{Ns} \operatorname{Arg}(\mathrm{Boc})-\mathrm{OBzl}(\mathbf{5})$}

To the mixture of mono-Boc-guanidine $(1 \mathrm{~g}, 6.3 \mathrm{mmol})$ and $\mathrm{Et}_{3} \mathrm{~N}(0.88 \mathrm{ml}, 6.3 \mathrm{mmol})$ in $\mathrm{DMF}$ at $0{ }^{\circ} \mathrm{C}$ a solution of Z-Cys $\left(\mathrm{SO}_{2} \mathrm{Cl}\right)$-OBzl (1.3 g, $\left.3.2 \mathrm{mmol}\right)$ in DMF was added dropwise. The reaction mixture was stirred at room temperature for $24 \mathrm{~h}$ and then hot water was added. The resulting oil was taken up with EtOAc and organic layer was washed subsequently with $5 \% \mathrm{NaHCO}_{3}, 5 \%$ $\mathrm{NaHSO}_{4}$ and brine. EtOAc was dried over $\mathrm{Na}_{2} \mathrm{SO}_{4}$, evaporated under reduced pressure and the resulting product was recrystalized from EtOAc/light petroleum (0.9 g, $52 \%$ yield $) .[\alpha]_{\mathrm{D}}^{22}=+2.6^{\circ}(c=1, \mathrm{DMF}) ; \mathrm{R}_{\mathrm{f}}(\mathrm{A})$ 0.98; $\mathrm{R}_{\mathrm{f}}$ (B) 0.76; MS-ES, $m / z: 535\left[\mathrm{M}^{+}\right] \mathrm{C}_{24} \mathrm{H}_{30} \mathrm{~N}_{4} \mathrm{O}_{8} \mathrm{~S}$ (534.595); ${ }^{1} \mathrm{H}-\mathrm{NMR}\left(\mathrm{CDCl}_{3}\right) \delta / \mathrm{ppm}: 8.0(\mathrm{~m}, 2 \mathrm{H}, \mathrm{NH})$, $7.1(\mathrm{~m}, 10 \mathrm{H}, \mathrm{Ar}), 5.3\left(\mathrm{~m}, 4 \mathrm{H}, \mathrm{CH}_{2} \mathrm{Ph}\right), 4.4(\mathrm{~m}, 1 \mathrm{H}, \mathrm{CH})$, $4.0\left(\mathrm{~m}, 2 \mathrm{H}, \mathrm{CH}_{2} \mathrm{SO}_{2}\right), 1.4(\mathrm{~s}, 9 \mathrm{H}, t-\mathrm{Bu}), 2.0(\mathrm{~s}, 2 \mathrm{H}, \mathrm{Gu})$.

\section{$\mathrm{Z}-\mathrm{NsArg}(\mathrm{Boc})-\mathrm{OH}(\mathbf{6})$}

$4(0.3 \mathrm{~g}, 0.6 \mathrm{mmol})$ was dissolved in a mixture of dioxane and water (volume ratio $=1: 1$ ) and $1 \mathrm{M}$ solution of $\mathrm{NaOH}$ was added dropwise until hydrolysis completed. Dioxane was evaporated in vacuo and the aqueous solution was acidified to $\mathrm{pH}=3$ and extracted with EtOAc $(3 \times 10 \mathrm{ml})$. The combined organic layers were washed with brine to $\mathrm{pH}=7$ and dried over $\mathrm{Na}_{2} \mathrm{SO}_{4}$. EtOAc was evaporated under reduced pressure and the product was recrystalized from $\mathrm{EtOH}$ to obtain $0.18 \mathrm{~g}$ (74\% yield). $\mathrm{C}_{17} \mathrm{H}_{24} \mathrm{~N}_{4} \mathrm{O}_{8} \mathrm{~S}$ (444.471); $\mathrm{R}_{\mathrm{f}}$ (B) 0.52, $\mathrm{R}_{\mathrm{f}}$ (C) 0.30; ${ }^{1} \mathrm{H}-\mathrm{NMR}\left(\mathrm{CDCl}_{3}\right) \delta / \mathrm{ppm}: 11.0(\mathrm{~s}, 1 \mathrm{H}, \mathrm{OH}), 8.0(\mathrm{~m}$, 2H, NH), 7.2 (m, 5H, Ar), $5.4\left(\mathrm{~m}, 2 \mathrm{H}, \mathrm{CH}_{2} \mathrm{Ph}\right), 4.5(\mathrm{~m}$, $1 \mathrm{H}, \mathrm{CH}), 3.9\left(\mathrm{~d}, 2 \mathrm{H}, \mathrm{CH}_{2} \mathrm{SO}_{2}\right), 1.4(\mathrm{~s}, 9 \mathrm{H}, t-\mathrm{Bu}), 2.0(\mathrm{~s}$, $2 \mathrm{H}, \mathrm{Gu})$.

\section{NsArg (7)}

$5(0.1 \mathrm{~g}, 0.2 \mathrm{mmol})$ was dissolved in DCM and mixture of $\mathrm{HBr}$ and $\mathrm{CH}_{3} \mathrm{COOH}(0.5 \mathrm{ml})$ was added. Deprotection was carried out for 1 hour at room temperature and the solvent was evaporated in vacuo. The solid residue was recrystalized from EtOEt to obtain $0.04 \mathrm{~g}$ (97\% yield). $[\alpha]_{\mathrm{D}}^{22}=+14.5^{\circ} \quad\left(c=1, \mathrm{H}_{2} \mathrm{O}\right) ; \mathrm{MS}-\mathrm{ES}, \mathrm{m} / z: 284\left[\mathrm{M}^{+}\right]$ $\mathrm{C}_{4} \mathrm{H}_{10} \mathrm{~N}_{4} \mathrm{O}_{4} \mathrm{~S}$ (283.152); ${ }^{1} \mathrm{H}-\mathrm{NMR}\left(\mathrm{CDCl}_{3}\right) \delta / \mathrm{ppm}: 11.0$ (s, $1 \mathrm{H}, \mathrm{OH}), 3.9\left(\mathrm{~d}, 2 \mathrm{H}, \mathrm{CH}_{2} \mathrm{SO}_{2}\right), 3.5(\mathrm{~m}, 1 \mathrm{H}, \mathrm{CH}), 2.0$ (d, 6H, $\mathrm{NH}_{2}, \mathrm{Gu}$ ).

$\mathrm{NsArg}-\mathrm{CONHNHC}_{6} \mathrm{H}_{5}$ (17)

$[\alpha]_{\mathrm{D}}^{22}=+24.3^{\circ}\left(c=1, \mathrm{H}_{2} \mathrm{O}\right) ; \mathrm{MS}-\mathrm{ES}, m / z: 163\left[\mathrm{M}^{+}\right]$ $\mathrm{C}_{4} \mathrm{H}_{10} \mathrm{~N}_{4} \mathrm{O}_{3}(162.15)$; 
anal. calcd. mass fraction $(w / \%)$ of $\mathrm{N}$ is 34.55 , found 34.6; IR (KBr) $\tilde{v}_{\max } / \mathrm{cm}^{-1}: 3420,3315,3033,1755$, $1687(\mathrm{C}=\mathrm{N}), 1610,1312,748 ;{ }^{1} \mathrm{H}-\mathrm{NMR}\left(\mathrm{D}_{2} \mathrm{O}\right) \delta / \mathrm{ppm}$ : 7.58 (s(br), 4H, guanidino-NH), $4.38(\mathrm{~m}, 1 \mathrm{H}, \alpha-\mathrm{CH})$, $2.20\left(\mathrm{~m}, 2 \mathrm{H}, \beta-\mathrm{CH}_{2}\right)$.

\section{Z-Ser(OPhth)-OBzl (8)}

Method I. To the solution of $2(0.8 \mathrm{~g}, 2 \mathrm{mmol})$ and $N$-hydroxyphthalimide $(0.65 \mathrm{~g}, 8 \mathrm{mmol})$ in THF $(20 \mathrm{ml})$ DBU $(0.6 \mathrm{ml}, 4 \mathrm{mmol})$ was added. The reaction mixture was stirred at room temperature for 24 hours. THF was evaporated in vacuo and the residue was dissolved in DCM $(30 \mathrm{ml})$ and was washed with water to $\mathrm{pH}=7$. The organic layer was dried over $\mathrm{Na}_{2} \mathrm{SO}_{4}$, filtered out and $\mathrm{CHCl}_{3}$ was evaporated in vacuo to obtain $0.41 \mathrm{~g}(89 \%$ yield) of 7. $[\alpha]_{\mathrm{D}}^{22}=+18.3^{\circ}(c=1$, DMF $)$; MS-ES, $m / z$ : $583\left[\mathrm{M}^{+}\right] \mathrm{C}_{37} \mathrm{H}_{30} \mathrm{~N}_{2} \mathrm{O}_{5}$ (582.66); $\mathrm{R}_{\mathrm{f}}(\mathrm{B})$ 0.81, $\mathrm{R}_{\mathrm{f}}$ (C) 0.75; ${ }^{1} \mathrm{H}-\mathrm{NMR}\left(\mathrm{CDCl}_{3}\right) \delta / \mathrm{ppm}: 8.1$ (m, 2H, Phth), 7.7 (m, 2H, Phth), 7.2 (m, 5H, Ar), 7.14-7.06 (m, 15H, Trt), 5.3 $\left(\mathrm{s}, 2 \mathrm{H}, \mathrm{CH}_{2}\right), 4.0\left(\mathrm{~d}, 2 \mathrm{H}, \mathrm{CH}_{2} \mathrm{O}\right), 3.5(\mathrm{~m}, 1 \mathrm{H}, \mathrm{CH})$.

Method II. The same as in method I, but with the following conditions at microwave irradiation $(300 \mathrm{~W})$, $1 \mathrm{~min}$ to $40{ }^{\circ} \mathrm{C}$, hold $5 \mathrm{~min}(0.42 \mathrm{~g}, 92 \%$ yield $)$.

\section{Z-NCan-OBzl (9)}

$7(0.4 \mathrm{~g}, 0.8 \mathrm{mmol})$ was dissolved in $\mathrm{EtOH}(4 \mathrm{ml})$ and $\mathrm{N}_{2} \mathrm{H}_{4} \cdot \mathrm{H}_{2} \mathrm{O}(0.5 \mathrm{ml})$ was added. The mixture was stirred at room temperature for 24 hours and $\mathrm{EtOH}$ was evaporated in vacuo. The residue was recrystalized from mixture of EtOAc and petroleum ether to obtain $0.24 \mathrm{~g}(85 \%$ yield) of 8. $\mathrm{C}_{18} \mathrm{H}_{20} \mathrm{~N}_{2} \mathrm{O}_{5}$ (344.37); $\mathrm{R}_{\mathrm{f}}$ (B) 0,74; $\mathrm{R}_{\mathrm{f}}$ (C) 0,61; ${ }^{1} \mathrm{H}-\mathrm{NMR}\left(\mathrm{CDCl}_{3}\right) \delta / \mathrm{ppm}: 9.0\left(\mathrm{~s}, 2 \mathrm{H}, \mathrm{NH}_{2}\right), 8.1$ (d, 1H, NH), $7.1(\mathrm{~m}, 10 \mathrm{H}, \mathrm{Ar}), 5.3\left(\mathrm{~s}, 4 \mathrm{H}, \mathrm{CH}_{2}\right), 4.51$ (m, 1H, CH), $4.1\left(\mathrm{~d}, 2 \mathrm{H}, \mathrm{CH}_{2} \mathrm{O}\right)$.

\section{$\mathrm{Z}-\mathrm{NCav}(\mathrm{Boc})_{2}-\mathrm{OBzl}$ (10)}

To the solution of 1H-pyrazol-1(N,N'-bis-Boc)-carboxamidine $(0.55 \mathrm{~g}, 1.6 \mathrm{mmol})$ and DIPEA $(0.7 \mathrm{ml}, 4$ $\mathrm{mmol})$ in $\mathrm{CH}_{3} \mathrm{CN}(4 \mathrm{ml})$ at room temperature, $8(0.57 \mathrm{~g}$, $1.6 \mathrm{mmol})$ was added. The mixture was stirred for 24 hours at room temperature. The solvent was evaporated in vacuo and the residue was dissolved in EtOAc $(20 \mathrm{ml})$ and was washed subsequently with $5 \% \mathrm{HCl}(2 \times 10 \mathrm{ml})$, brine and was dried over $\mathrm{Na}_{2} \mathrm{SO}_{4}$. EtOAc was evaporated in vacuo and the resulting product was recrystalized from mixture of EtOAc and hexane to obtain 0.37 g (42\% yield). $\mathrm{C}_{29} \mathrm{H}_{38} \mathrm{~N}_{4} \mathrm{O}_{9}(586.65) ; \mathrm{R}_{\mathrm{f}}(\mathrm{B}) 0.9 ; \mathrm{R}_{\mathrm{f}}(\mathrm{C})$ $0.91 ;{ }^{1} \mathrm{H}-\mathrm{NMR}\left(\mathrm{CDCl}_{3}\right) \delta / \mathrm{ppm}: 8.0(\mathrm{~d}, 3 \mathrm{H}, \mathrm{NH}), 7.2$ (m, 10H, Ar), $5.4\left(\mathrm{~s}, 4 \mathrm{H}, \mathrm{CH}_{2}\right), 4.51(\mathrm{~m}, 1 \mathrm{H}, \mathrm{CH}), 4.1$ (d, $\left.2 \mathrm{H}, \mathrm{CH}_{2} \mathrm{O}\right), 1.4(\mathrm{~s}, 18 \mathrm{H}, t-\mathrm{Bu})$.

\section{$\mathrm{Z}-\mathrm{NCav}(\mathrm{Boc})_{2}-\mathrm{OH}(11)$}

$9(0.29 \mathrm{~g}, 0.6 \mathrm{mmol})$ was dissolved in a mixture of dioxane and water (volume ratio $=1: 1$ ) and $1 \mathrm{M}$ solution of $\mathrm{NaOH}$ was added dropwise until the hydrolysis was complete. Dioxane was evaporated in vacuo and the aqueous solution was acidified to $\mathrm{pH}=3$ and extracted with EtOAc $(3 \times 10 \mathrm{ml})$. The combined organic layers were washed with brine to $\mathrm{pH}=7$ and dried over $\mathrm{Na}_{2} \mathrm{SO}_{4}$. EtOAc was evaporated under reduced pressure and the product was recrystalized from EtOH to obtain $0.18 \mathrm{~g}(76 \%$ yield $)$.

\section{$\operatorname{NCav}(12)$}

10 (0.15 g, $0.3 \mathrm{mmol})$ was dissolved in DCM and mixture of $\mathrm{HBr}$ and $\mathrm{CH}_{3} \mathrm{COOH}(0.5 \mathrm{ml})$ was added. Deprotection was carried out for 1 hour at room temperature and the solvent was evaporated in vacuo. The solid residue was recrystalized from EtOEt to obtain $0.047 \mathrm{~g}$ (96\% yield). $[\alpha]_{\mathrm{D}}^{22}=+24.3^{\circ}\left(c=1, \mathrm{H}_{2} \mathrm{O}\right)$; MS-ES, $m / z$ : $163\left[\mathrm{M}^{+}\right] \mathrm{C}_{4} \mathrm{H}_{10} \mathrm{~N}_{4} \mathrm{O}_{3}$ (162.15); anal. calcd. mass fraction $(w / \%)$ of $\mathrm{N}$ is 34.55 , found 34.6 ; IR $(\mathrm{KBr})$ $\tilde{v}_{\max } / \mathrm{cm}^{-1}: 3420,3315,3033,1755,1687(\mathrm{C}=\mathrm{N}), 1610$, 1312, 748; ${ }^{1} \mathrm{H}-\mathrm{NMR}\left(\mathrm{D}_{2} \mathrm{O}\right) \delta / \mathrm{ppm}: 7.58(\mathrm{~s}(\mathrm{br}), 4 \mathrm{H}$, guanidino-NH), $4.38(\mathrm{~m}, 1 \mathrm{H}, \alpha-\mathrm{CH}), 2.20\left(\mathrm{~m}, 2 \mathrm{H}, \beta-\mathrm{CH}_{2}\right)$.

\section{Boc-Ser-Wang-Resin (13)}

In a round bottom flask the resin was suspended in $7 \mathrm{ml}$ of mixture of $\mathrm{CH}_{2} \mathrm{Cl}_{2}$ and DMF (volume ratio = 9:1). In a separate flask, Boc-Ser (12) was dissolved in a minimum amount of DMF (4 ml). The same equivalence of HOBt was added. The mixture was stirred until the HOBt was dissolved. This solution was added to the resin. In a separate flask $\mathrm{Et}_{3} \mathrm{~N}$ was dissolved in a minimum amount of DMF $(1 \mathrm{ml})$. HBTU was added to the resin mixture then the DMAP solution was added. The mixture was shaken for 2 hours at room temperature. The resin was filtered and washed 3 times with DMF, then 3 times with DCM, and finally 3 times with methanol. In each wash, enough solvent was used to slurry the resin. After the final methanol wash, the resin was dried in vacuo to a constant weight. The substitution of the resin can be estimated from the weight gain of the resin.

\section{Boc-Ser(OPhth)-Resin (14)}

Method I. Boc-Ser-Resin (0.25 g, $0.18 \mathrm{mmol})$ was suspended in DMF ( $5 \mathrm{ml})$ and TPP $(0.12 \mathrm{~g}, 0.45 \mathrm{mmol})$ and $N$-hydroxyphthalimide $(0.06 \mathrm{~g}, 0.36 \mathrm{mmol})$ were added subsequently. DEAD $(0.08 \mathrm{ml}, 0.45 \mathrm{mmol})$ was added and the mixture was shaken for 2 hours at room temperature. The resin was filtered and washed 5 times with DMF.

Method II. The same as in method I, but with the following conditions at microwave irradiation $(300 \mathrm{~W})$, ( 1 min to $40{ }^{\circ} \mathrm{C}, 4 \times 30 \mathrm{~s}$ hold).

\section{Boc-NCan-Resin (15)}

$14(0.95 \mathrm{~g}, 2 \mathrm{mmol})$ and $\mathrm{N}_{2} \mathrm{H}_{4} \cdot \mathrm{H}_{2} \mathrm{O}(2 \mathrm{ml})$ were suspended in EtOH $(10 \mathrm{ml})$. The mixture was shaken for 2 hours at room temperature. The resin was filtered and washed 3 times with EtOH and 3 times with DMF.

\section{Boc-NCav(Boc) ${ }_{2}$-Resin (16)}

Method I. The solution of $1 \mathrm{H}$-pyrazol-1( $N, N^{\prime}$-bis-Boc)carboxamidine $(0.55 \mathrm{~g}, 1.6 \mathrm{mmol})$ and DIPEA $(0.7 \mathrm{ml}$, $4 \mathrm{mmol})$ in $\mathrm{CH}_{3} \mathrm{CN}(4 \mathrm{ml})$ was added at room tempera- 
ture to $\mathbf{1 5}$. The mixture was shaken for 24 hours at room temperature. The resin was filtered and washed 3 times with $\mathrm{CH}_{3} \mathrm{CN}$ and 3 times with DMF.

Method II. The same as in method I, but with the following conditions at microwave irradiation (300W), $1 \mathrm{~min}$ to $40^{\circ} \mathrm{C}$, hold $5 \mathrm{~min}$.

\section{$\operatorname{NCav}(11)$}

Cleavage of $\mathbf{1 1}$ from the resin was achieved with acidic hydrolysis with $5 \mathrm{ml}$ of $95 \%$ TFA for $30 \mathrm{~min}$. The resin was filtered out and the solvent was evaporated in vacuo. $\mathrm{NCav}$ was obtained as a white solid ( $0.03 \mathrm{~g}, 53 \%$ yield).

\section{HPLC-characterization of Reaction Products 7 and 12}

All samples were prepared in a concentration of $1 \mathrm{mg}$ $\mathrm{ml}^{-1}$ and dissolved in the mobile phase. Mobile phases were degassed for $10 \mathrm{~min}$ by helium 5.0.

Determination of Purity of Crude Products 7 and 12 HPLC analysis of the products were performed on a column Beckman Ultrasphere ${ }^{\mathrm{TM}} \mathrm{RPC}_{18}(250 \times 4.6 \mathrm{~mm}$, $5 \mu \mathrm{m})$ with a mobile phase: mixture of $0.01 \mathrm{M} \mathrm{K}_{2} \mathrm{HPO}_{4}$ $(\mathrm{pH}=2.5)$ and acetonitrile (volume ratio $=80: 20)$ over $30 \mathrm{~min}$ at a flow rate of $0.5 \mathrm{ml} \mathrm{min}{ }^{-1}$. Detection was performed at $230 \mathrm{~nm}$.

Sample analysis carried out on column $\mathrm{ZIC}^{\circledR}$ HILIC $(100 \times 4.6 \mathrm{~mm}, 5 \mu \mathrm{m})$ with a mobile phase: mixture of $0.05 \mathrm{M} \mathrm{CH}_{3} \mathrm{COONH}_{4}(\mathrm{pH}=6.8)$ and acetonitrile (volume ratio $=50: 50$ ) for NCav, and mobile phase: mixture of $0.005 \mathrm{M} \mathrm{CH}_{3} \mathrm{COONH}_{4}(\mathrm{pH}=6.8)$ and acetonitrile (volume ratio $=20: 80$ )for NsArg, respectively at a flow rate $0.5 \mathrm{ml} \mathrm{min}^{-1}$. Detection was performed at 230 and $254 \mathrm{~nm}$.

Determination of Enantiomeric Purity of the Crude Products 7 and $\mathbf{1 2}$

Micro-HPLC analysis of the products were performed on a column packed with the macrocyclic antibiotic Ristocetin A immobilized on $3.5 \mu \mathrm{m}$ silica gel $(100 \times 1$ $\mathrm{mm}$ ) with a mobile phase: mixture of $0.1 \%$ TEAA in water $(\mathrm{pH}=6.9)$ and methanol (volume ratio $=80: 20)$ at a flow rate $30 \mu \mathrm{min}^{-1}$. Detection was performed at $208 \mathrm{~nm}$.

\section{Incubation with Drugs and In Vitro Cytotoxicity Test}

Murine erythroleukemia cells, clone $\mathrm{F} \mathrm{N}^{17}$ were cultured in Dulbecco's modified Eagle medium supplemented with $10 \%$ calf serum, under a $5 \% \mathrm{CO}_{2}$ atmosphere at $37{ }^{\circ} \mathrm{C}$, and passed every day at a concentration of $5 \times 10^{5}$ cells $\mathrm{ml}^{-1}$.

The inhibitors were dissolved immediately before use in DMSO to obtain stock solutions of different concentrations. Each of these solutions was used at $1 \%$ concentration in the experiments with F4N cells. Control samples were incubated in the presence of $1 \%$ DMSO. The final concentration of DMSO in the medium did not affect cell growth.
Exponentially growing cells $\left(0.5 \times 10^{6}\right.$ cells $\left.\mathrm{ml}^{-1}\right)$ were incubated in triplicate with increasing concentrations of the test complexes in 96-well microtiter plates. After 24, 48 and $72 \mathrm{~h}$ of drug treatment, the cells were counted hemocytometrically. The number of dead cells was determined by staining with trypan blue. The mean of triplicate determinations of three independent experiments was calculated. The $50 \%$ inhibitory dose (IC50) was defined as drug concentration that reduces the number of living cells by $50 \%$.

\section{RESULTS AND DISCUSSION}

We have recently reported a general synthetic route to sulfo- and oxo-analogues of Arg., ${ }^{8,9}$

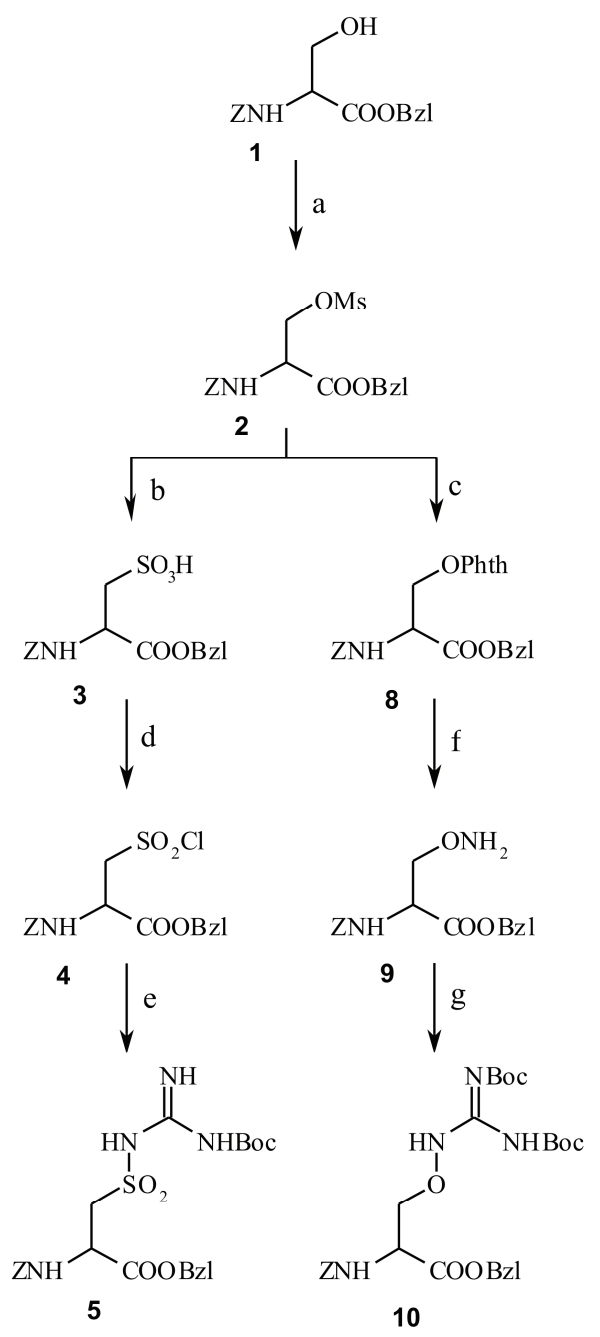

a) $\mathrm{CH}_{3} \mathrm{SO}_{2} \mathrm{Cl} / \mathrm{DIPEA} / \mathrm{DMF}$; b) $\mathrm{Na}_{2} \mathrm{SO}_{3} / \mathrm{H}_{2} \mathrm{O}$ (or MW irradiation); c) $\mathrm{N}$-Hydroxyphthalimide/ $\mathrm{NaH} / \mathrm{DMF}$ (or MW irradiation); d) $\mathrm{SO}_{2} \mathrm{Cl} / \mathrm{CH}_{2} \mathrm{Cl}_{2}$; e) mono-Boc-Guanidine/Et 3 N/DMF; f) $\mathrm{N}_{2} \mathrm{H}_{4} \cdot \mathrm{H}_{2} \mathrm{O} / \mathrm{EtOH}$; g) $\mathrm{Boc}_{2}$-pyrazole/ $\mathrm{CH}_{3} \mathrm{CN} / \mathrm{DIPEA}$

Scheme 1. Synthesis of NsArg and NCav. Reagents and conditions. 
As outlined at the Scheme 1, sulfo- and oxoanalogues of Arg (Figure 1) were prepared for the first time starting from the same key compound Ser. The first steps of this route were common for obtaining the mesylated fully protected Ser (2) and after that we prepared NCav (12) and NsArg (7) analogues.

For the preparation of NsArg (7) we applied a new approach - synthesis of sulfonyl chloride (4) via sulfonic $\operatorname{acid}^{18}(3)$ by conventional synthesis in solution or in conditions of microwave irradiation. In the second case the reaction time was shortened from 24 hours to 5 minutes. All other steps of this synthetic scheme have been previously described.

NCav (12) was synthesized by using two different approaches. The first was based on conventional methods in solution (Scheme 1), the second - on solid phase organic synthesis (Scheme 2). In some steps of both synthetic schemes we applied for first time microwave irradiation. In conditions of MWA, SPS on the first and second stages reaction was carried out at 40 degrees and an irradiation time of totally 2 minutes. Introduction of guanidine group was made also in the MWA synthesis at 40 degrees and irradiation time of 5

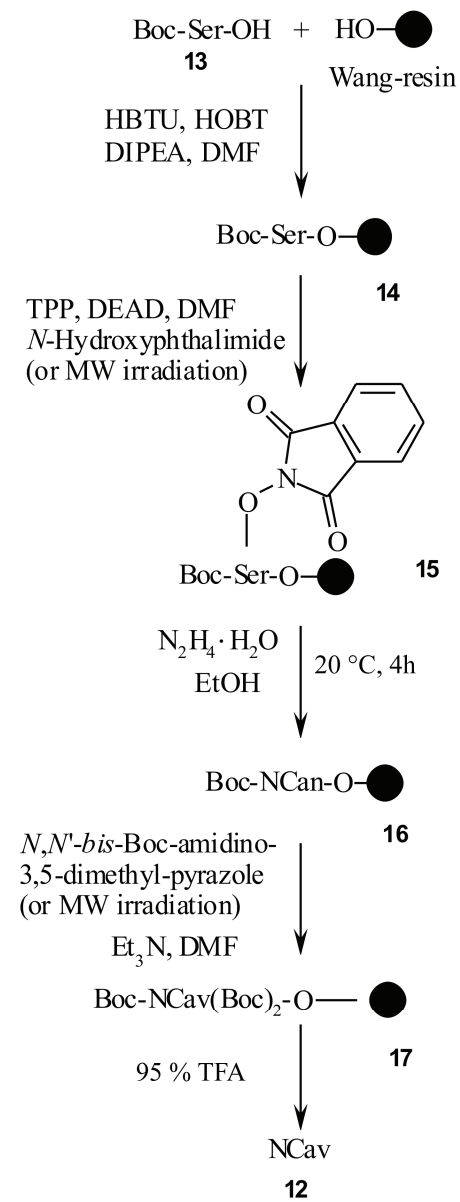

Scheme 2. Synthesis of NCav on solid support. Reagents and conditions. minutes.

The synthesis of the hydrazide derivatives of NsArg and NCav (Figure 1) has been described previously. ${ }^{8,9}$ Both of the hydrazides, NsArg$\mathrm{CONHNHC}_{6} \mathrm{H}_{5}$ (18) and $\mathrm{NCav}_{-} \mathrm{CONHNHC} \mathrm{H}_{5}$ (19) were prepared by a condensation reaction of the corresponding di-protected compound with the Boc$\mathrm{NHNHC}_{6} \mathrm{H}_{5}$ in the presence of DIPEA, using TBTU reagent. The condensation method we have applied afforded high purity products and column chromatography purification was not required. Moreover, it should be noted that under the mild conditions of the synthesis, undesirable side processes, including racemization, did not take place. Cleavage of the protecting Boc-group was achieved by ethyl acetate saturated by ethyl acetate saturated anhydrous $\mathrm{HCI}$ (mixture of $1.5 \mathrm{M} \mathrm{HCl}$ and EtOAC), or mixture of TFA and anisole (volume ratio = $9: 1$ ) in $95-98 \%$ yields.

In conjunction with these synthesis routes, analytical methods are required to monitor the chemical and enantiomeric purity of the formed products. Using optimized conditions described above, excellent purity obtained of 7 (98\%) and 12 (96\%) in the crude HPLCchromatograms (Figures 2 and 3). For most applications the purity of these products will be sufficient.

To determine whether the MWA conditions resulted in racemization at the $\alpha$-amino center, 7 and $\mathbf{1 2}$ were evaluated for enantiomeric purity. As several UAA were successfully analyzed by us using macrocyclic antibiotic phases, ${ }^{19}$ it was decided to adapt this well established method for the chiral analysis of NCav and NsArg.

The resulting chromatograms did not show detect-

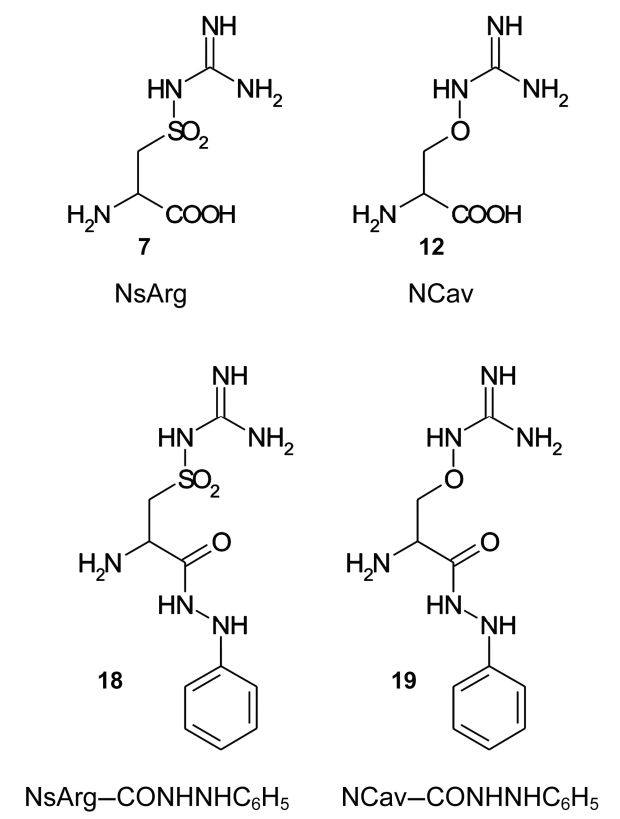

Figure 1. Structures of NsArg, NCav and their phenylhydrazides. 


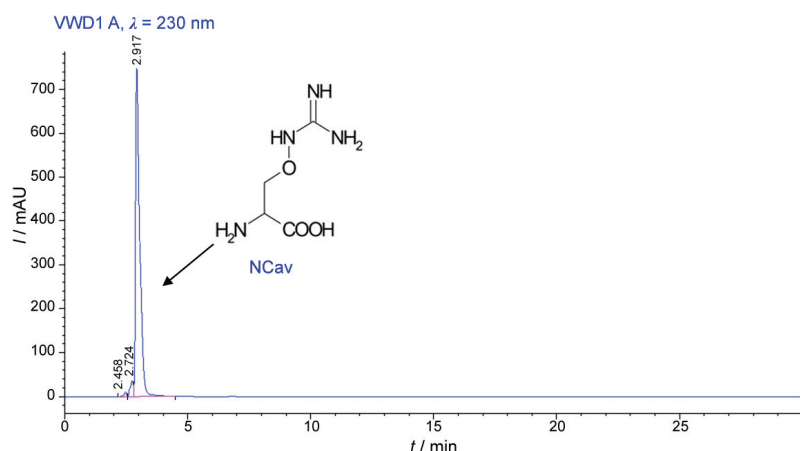

Figure 2. HPLC-chromatogram of crude NCav. Column: Beckman Ultrasphere ${ }^{\mathrm{TM}} \mathrm{RPC}_{18}(250 \times 4.6 \mathrm{~mm})$; mobile phase: mixture of $0.01 \mathrm{M} \mathrm{K}_{2} \mathrm{HPO}_{4}(\mathrm{pH}=2.5)$ and acetonitrile (volume

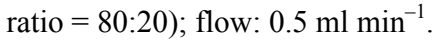

able diastereomeric contamination, indicating that the ee value of 12 is $>98.9 \%$ (Figure 4 ).

The elemental analysis and spectral data confirmed the structures of the sulfo- and oxo-analogues of Arg shown in Figure 1, and were in accordance with the data reported in our previous papers. ${ }^{8,9}$

\section{Cytotoxic Effect}

The cytotoxicity of NCav, NCav-CONHNHC $\mathrm{H}_{6}$, NsArg, NsArg-CONHNHC ${ }_{6} \mathrm{H}_{5}$ in F4N cells was examined using cell-growth assay. The growth-inhibitory effects of 24, 48 and $72 \mathrm{~h}$ incubation of the cells with the drugs are expressed by IC50 values (Table 1). Clear differences in the cell growth were observed after 48 and $72 \mathrm{~h}$ of incubation. IC50 values of NCav were found to be 8 and $3.2 \mathrm{mmol} \mathrm{dm}^{-3}$ after 48 and $72 \mathrm{~h}$ incubation respectively, while those of NCav-CONH-

Table 1. Cytotoxicity of sulfo- and oxyguanidine arginine analogues in F4N cells

\begin{tabular}{|c|c|c|c|}
\hline \multirow[t]{2}{*}{ Compound } & \multicolumn{3}{|c|}{ 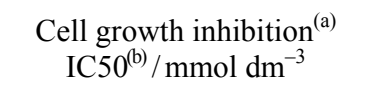 } \\
\hline & 24 & 48 & 72 \\
\hline $\mathrm{NCav}$ & $>8$ & 8 & 3.2 \\
\hline $\mathrm{NCav}_{-\mathrm{CONHNHC}} \mathrm{H}_{5}$ & $>8$ & 2.5 & 1.3 \\
\hline NsArg & 4 & 3.3 & 2.4 \\
\hline $\mathrm{NsArg}_{\mathrm{CONHNHC}} \mathrm{H}_{5}$ & 4.6 & 1.7 & 0.8 \\
\hline $\mathrm{Cav}^{(\mathrm{c})}$ & $>6$ & 5.5 & 1.7 \\
\hline $\mathrm{CPH}^{(\mathrm{c})}$ & 0.44 & 0.315 & 0.23 \\
\hline
\end{tabular}

(a) Exponentially growing cells were incubated in culture medium for 24,48 and $72 \mathrm{~h}$ at $37^{\circ} \mathrm{C}$ with varying amounts of the compounds and counted thereafter hemocytometrically. The number of dead cells was determined by trypane blue exclusion.

(b) Drug concentration that reduces the number of living cells by $50 \%$. Values are means of triplicate determination in at least two independent experiments.

${ }^{\text {(c) }}$ Results from our previous research. ${ }^{10}$
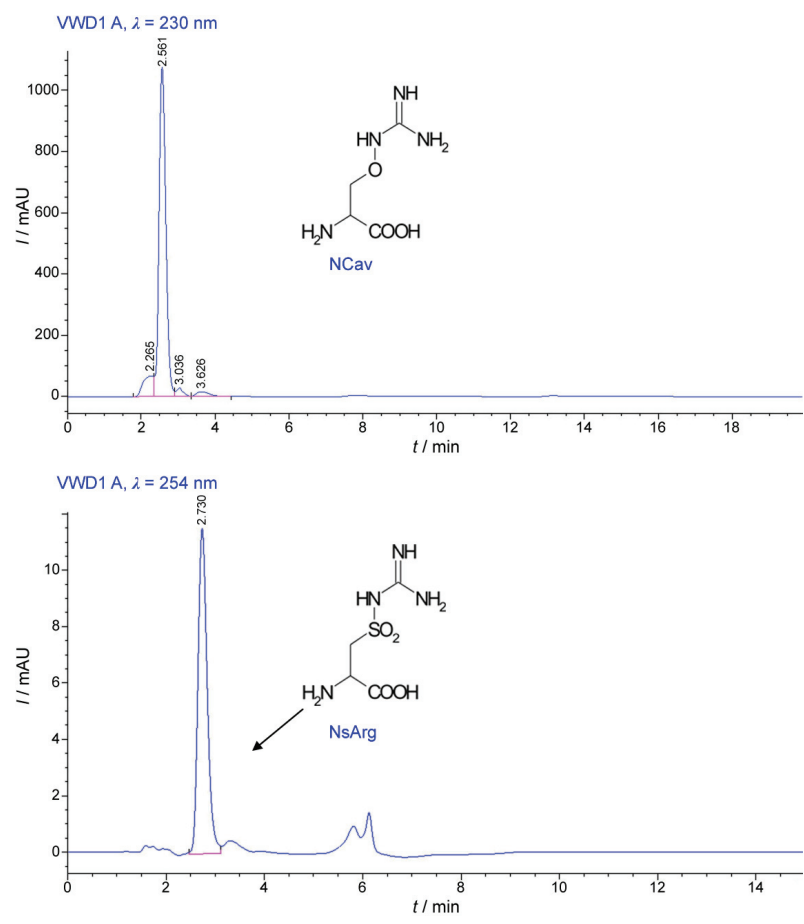

Figure 3. HPLC-chromatograms of crude NCav (top) and NSArg (bottom).Column: ZIC ${ }^{\circledR}$-HILIC $(100 \times 4.6 \mathrm{~mm})$; mobile phase: mixture of $0.05 \mathrm{M} \mathrm{CH}_{3} \mathrm{COONH}_{4}(\mathrm{pH}=6.8)$ and acetonitrile (volume ratio $=50: 50$ ) for $\mathrm{NCav}$, and mobile phase: mixture of $0.005 \mathrm{M} \mathrm{CH}_{3} \mathrm{COONH}_{4}(\mathrm{pH}=6.8)$ and acetonitrile (volume ratio $=20: 80$ ) for NsArg, respectively; flow: $0.5 \mathrm{ml} \mathrm{min}^{-1}$.

$\mathrm{NHC}_{6} \mathrm{H}_{5}$ were 2.5 and 1.3. The second compound proved to be 3 times more cytotoxic than NCav. Similar results were obtained for NsArg and its phenylhydrazide derivative $\mathrm{NsArg}-\mathrm{CONHNHC}{ }_{6} \mathrm{H}_{5}$. The concentrations of NsArg reducing the number of living cells by $50 \%$ ranged from 4 to $2.4 \mathrm{mmol} \mathrm{dm}^{-3}$ for the different times of treatment, while those of NsArg-CONHNHC${ }_{6} \mathrm{H}_{5}$ ranged from 4.6 to $0.8 \mathrm{mmol} \mathrm{dm}{ }^{-3}$. These results con-

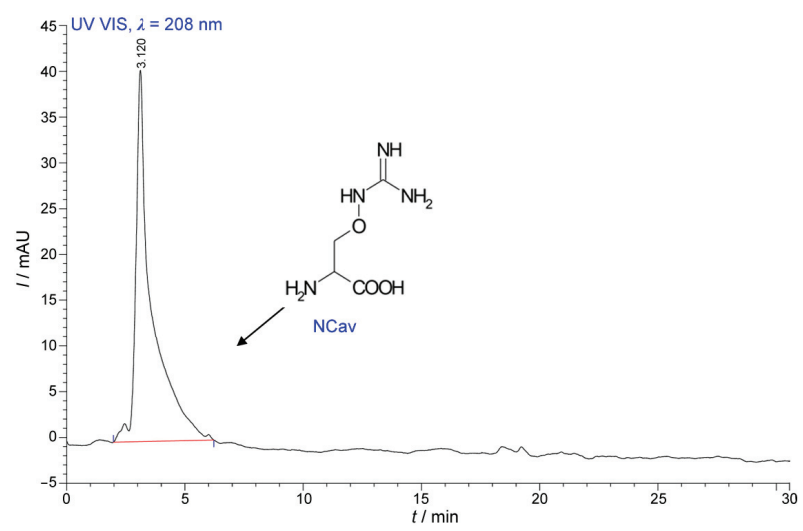

Figure 4. Determination of chiral purity of $\mathrm{NCav}$ on a Ristocetin A phase. Column: $100 \times 1 \mathrm{~mm}$; mobile phase: mixture of $0.1 \%$ solution of TEAA in water $(\mathrm{pH}=6.9)$ and methanol (volume ratio $=80: 20$ ); flow: $30 \mu 1 \mathrm{~min}^{-1}$. 
firm our previous findings, showing that $\mathrm{CPH}$ was more cytotoxic than Cav by almost an order of magnitude. ${ }^{10}$ NsArg ant its phenylhydrazide derivative exhibit higher cytotoxicity compared to the respective NCav compounds.

In conclusion, the main goal of the chemical approach applied was a quick and efficient preparation of NCav and NsArg of high purity, in a quantity sufficient for biological testing. That was achieved, since the HPLC data of the amino acid analogues revealed $95 \%$ average purity, based on the relative peak area with monitoring at 230 and $254 \mathrm{~nm}$. In addition $1 \%$ of the unwanted enantiomer was detected. All tested compounds showed cytotoxic activity against F4N cells. Phenylhydrazide derivatives proved to be more cytotoxic than their parent compounds in accordance with our previous results.

Acknowledgements. We are grateful to the the Bulgarian Ministry of Education and Science and NFSR of Bulgaria (Contract MY-FS-13-07) and CEEPUS II HU-0010.

\section{REFERENCES}

1. P. Thamm, W. Kolbeck, H. J. Musiol, and L. Moroder, Synthesis of Peptides and Peptidomimetics, in: M. Goodman, A. Felix, L. Moroder, and C.Tonilio, (Eds.), Houben-Weyl, Methods of Organic Chemistry Vol. E22, Georg Thieme, Stuttgart, 2001, pp. 315-333.

2. D. W. Choi and S. M. Rothman, Annu. Rev. Neurosci. 13 (1990) 171-182.

3. M. A. Dorheim, W. R., Tracey, J. S. Pollock, and P. Grammas, Biochem. Biophys. Res. Commun. 205 (1994) 659-665.

4. P. Kubes, M. Suzuki, D. N. Granger, Proc. Natl. Acad. Sci. U. S. A. 88 (1991) 4651-4655.

5. L. Peterlin-Mašič and D. Kikelj, Tetrahedron 57 (2001) 70737105.

6. T. Pajpanova, S. Stoev, E. Golovinsky, G.-J. Krauss, and J. Miersch, Amino Acids 12 (1997) 191-204.
7. M. Stanchev, T. Pajpanova, and E. Golovinsky, Amino Acids $\mathbf{1 8}$ (2000) 177-191.

8. T. Dzimbova, T. Pajpanova, and E. Golovinsky, Collect. Czech. Chem. Commun. 6 (2003) 12-14.

9. T. Dzimbova, T. Pajpanova, S. Tabakova, and E. Golovinsky, in: P. A. Cordopatis, E. Manessi-Zoupa, and G. N. Pairas (Eds.), $5^{\text {th }}$ Hellenic Forum on Bioactive Peptides,Typorama, Patras, 2007, p. 223.

10. J. Miersh, K. Grancharov, T. Pajpanova, D. Neumann, S. Tabakova, S. Stoev, G.-J. Krauss and E. Golovinsky, Amino Acids $\mathbf{1 8}$ (2000) 41-59.

11. J. Miersch, K. Grancharov, T. Pajpanova, G.-J. Krauss, R. Baumbach, S. Tabakova, and E. Golovinsky, Ecological significance of canavanine and biological activity of some canavanine derivatives, in: P. P. Dedeyn, B. M., V. Stalon, J. A. Qureshi. (Eds.), Guanidino Compounds in Biology and Medicine, John Libley \& Co. Ltd., London, 1997, pp. 401-405.

12. T. Pajpanova, A. Bocheva, and E. Golovinsky, Meth. Find. Exp. Clin. Pharmacol. 21 (1999) 591-594.

13. N. Pencheva, P. Milanov, L. Vezenkov, T. Pajpanova, E. Naydenova, Eur. J. Pharmacol. 498 (2004) 249-256.

14. S. Pancheva, R. Kalauzka, E. Popgeorgieva, and T. Pajpanova, in: M. Flegl, S. Slaninova, M. Fridkin, and C. Gilon (Eds.), Peptides 2004. Bridges Between Disciplines, Kenes International, Geneva, 2005, p. 950.

15. M. Spasova, S. Pancheva, T. Pajpanova, Ts. Milkova, G. Dibo, E. Dzambazova, H. Nocheva, and A. Bocheva, in: K. Rolka, P. Rekowski, and J. Silberring (Eds.), Peptides 2006, Kenes International, Geneva, 2007, p. 728.

16. F. Liu, J. Thomas, and T. R. Burkle Jr., Synthesis 15 (2008) 2432-2438.

17. S. K. Dube, I. B. Pragnell, N. Kluge, G. Gaedicke, G. Steinheider, and W. Ostertag, Proc. Natl. Acad. Sci. U. S. A. 72 (1975) 1863-1867.

18. K. G. Carson, C. F. Schwender, H. N. Shroff, N. A. Cochran, D. L. Gallant, and M. J. Briskin, Bioorg. Med. Chem. Lett. 7 (1997) 711-714.

19. A. M. Piccinini, E. Grueva, S. Pancheva, T. Pajpanova, M. Schmid, G. Gübitz, J. Biochem. Biophys. Methods 61 (2004) $11-21$. 